Review

\title{
The fate of patulin in apple juice processing: A review
}

\author{
Anderson de Souza Sant'Ana ${ }^{\mathrm{a}, *}$, Amauri Rosenthal ${ }^{\mathrm{b}}$, Pilar Rodriguez de Massaguer ${ }^{\mathrm{a}, *}$ \\ ${ }^{a}$ Department of Food Science, Faculty of Food Engineering, State University of Campinas - UNICAMP, Rua Monteiro Lobato, 80, Caixa Postal: 6121, CEP: 13083-862 \\ Campinas, SP, Brazil \\ b Brazilian Agricultural Research Corporation - EMBRAPA, Avenida das Américas, 29.501 Guaratiba, CEP: 23020-470 Rio de Janeiro, RJ, Brazil
}

\section{A R T I C L E I N F O}

\section{Article history:}

Received 23 October 2007

Accepted 3 March 2008

\section{Keywords:}

Patulin

Apple juice

Control methods

Juice processing

Mycotoxins

\begin{abstract}
A B S T R A C T
This article is a review about the effects of each of the processing stages of pasteurized apple juice on the increase, prevalence or reduction of patulin (PAT) levels in the final product. Recommendations are included for the control and reduction of the incidence of the moulds that produce it and the mycotoxin itself, from the pre-harvest to the final manufacturing stages of apple juice, studies required for a better understanding of the behaviour of this mycotoxin during processing also being indicated. Although the initial stages of the juice manufacturing process (washing, selection and trimming) are highly efficient in reducing the levels of PAT, control of the mycotoxin should always be focused on the production stages of the process that guarantee the inhibition of its production (pre-harvest, harvest and post-harvest).

(c) 2008 Elsevier Ltd. All rights reserved.
\end{abstract}

\section{Contents}

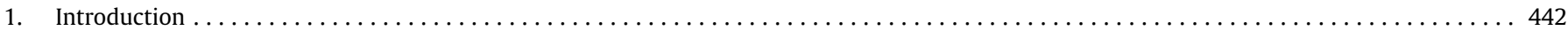

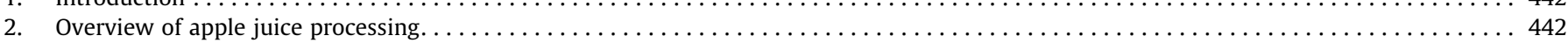

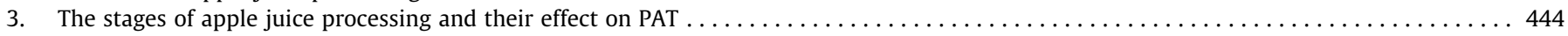

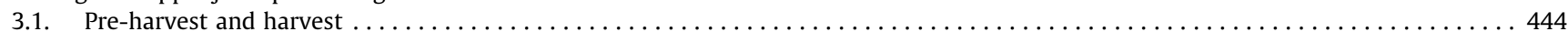

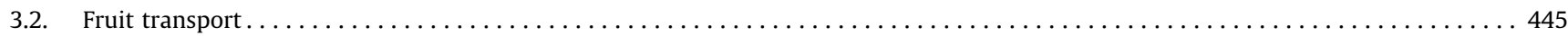

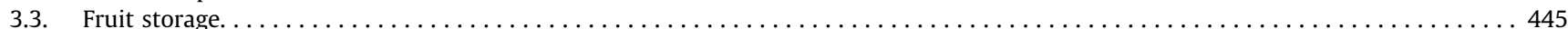

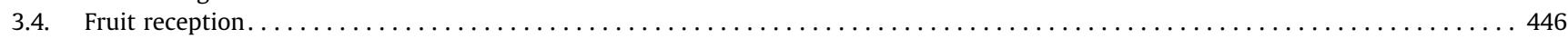

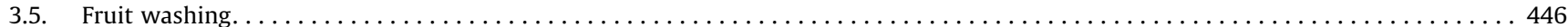

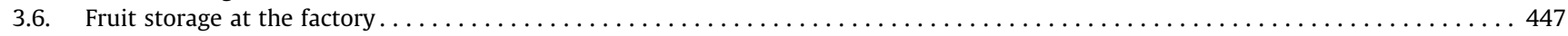

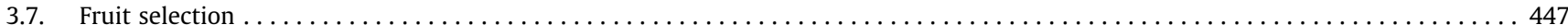

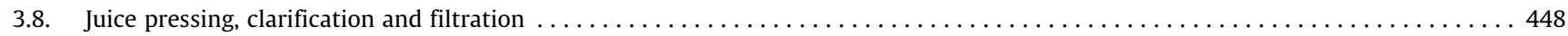

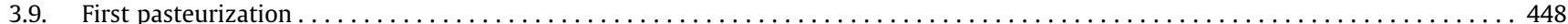

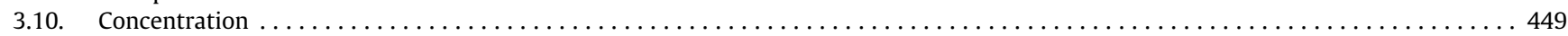

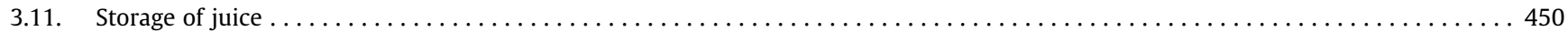

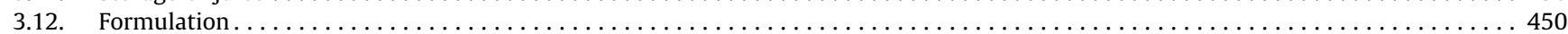

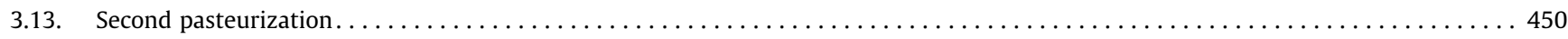

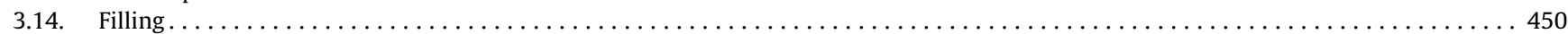

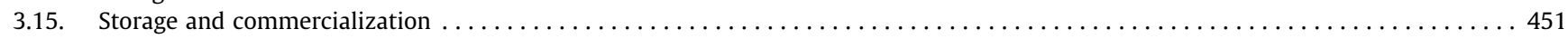

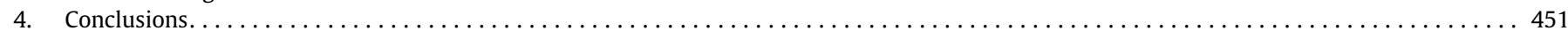

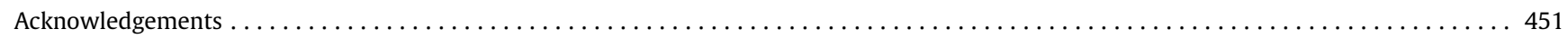

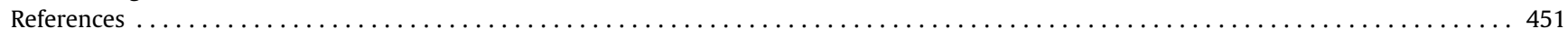

\footnotetext{
* Corresponding authors. Tel.: +55 193521 2174; fax: +55 1932894966.

E-mail addresses: assantana@hotmail.com, asantana@fea.unicamp.br (A.S. Sant'Ana), esteril@unicamp.br (P.R. de Massaguer).
} 


\section{Introduction}

Patulin (PAT) is a toxic metabolite produced by various species of Penicillium, Aspergillus and Byssochlamys (Harrison, 1989). Penicillium and Aspergillus can be considered as the main species responsible for the production of the mycotoxin in the pre-processing stages of the fruit (pre-harvest and post-harvest). Some species of Byssochlamys can be considered as potential producers of the mycotoxin in the post-pasteurization stages, due to their capacity to survive the heat treatment commonly applied to fruit juices.

Chemically, PAT [4-hydroxy-4-H-furo(3,2-c)pyran-2(6H)-one], is an unsaturated heterocyclic lactone with an empirical formula of $\mathrm{C}_{7} \mathrm{H}_{6} \mathrm{O}_{4}$ and a molecular weight of 154 (Fig. 1) (Stott \& Bullerman, 1975).

Various acute and chronic effects and others at the cellular level have been attributed to PAT. The acute symptoms include nervousness, convulsions, lung congestion, oedema, hyperaemia, gastrointestinal tract distension, intestinal haemorrhage and epithelial cell degeneration (Escoula, Moore, \& Baradat, 1977; Hayes, Phillips, Williams, \& Ciegler, 1979; Mahfoud, Maresca, Garmy, \& Fantini, 2002). The chronic symptoms include genotoxic (Pfeiffer, Groß, \& Metzler, 1998), neurotoxic (Hopkins, 1993), immunotoxic, immunosuppressive (Wichmann, Herbarth, \& Lehmann, 2002), and teratogenic (Roll, Matthiaschk, \& Korte, 1990) effects. At the cellular level, some examples of these effects are plasmatic membrane rupture (Mahfoud et al., 2002), protein synthesis inhibition (Arafat \& Musa, 1995), and DNA and RNA synthesis inhibition (Cooray, Kiessling, \& Lindahl-Kiessling, 1982; Moule \& Hatey, 1977).

Due to evidence of the adverse effects of this mycotoxin, the Codex Alimentarius (Codex, 2003a) and the FDA (2000) have recommended a maximum level of $50 \mu \mathrm{g} / \mathrm{L}$ for fruit juices and their products. According to regulation 1425/2003 of the European Common Market (European Union, 2003), a level of $25 \mu \mathrm{g} / \mathrm{L}$ for solid apple products and $10 \mu \mathrm{g} / \mathrm{L}$ for juices and foods for infants has been recommended.

PAT has been found mainly in apples and its products, and occasionally in other fruits such as pears, apricots, peaches and grapes, being produced in the rotten parts of these fruits (Cheraghali et al., 2005). In apple juice, the mycotoxin has been detected in various countries around the World, such as Finland (Lindroth \& Niskanen, 1978), the USA (Brackett \& Marth, 1979a), Australia (Burda, 1992; Watkins, Fazekas, \& Palmer, 1990), Chile (Canãs \& Aranda, 1996), Spain (Prieta, Moreno, Díaz, Suárez, \& Dominguez, 1994), Brazil (Iha \& Sabino, 2008; Prado et al., 2000; Sylos \& Rodriguez-Amaya, 1999; Manchisky \& Mídio, 1996), Turkey (Gökmen \& Acar, 1998, 2000; Yurdun, Omurtag, \& Ersoy, 2001), Japan (Watanabe \& Shimizu, 2005), South Africa (Leggott \& Shephard, 2001), Iran (Cheraghali et al., 2005), The Netherlands (Boonzaaijer, Bobeldijk, \& van Osenbruggen, 2005), France (Leblanc, Tard, Volatier, \& Verger, 2005), Italy (Beretta, Gaiaschi, Galli, \& Restani, 2000; Piemontese, Solfrizzo, \& Visconti, 2005; Ritieni, 2003; Spadaro, Ciavorella, Frati, Garibaldi, \& Gullino, 2007), Belgium (Baert, Meulenaer, Kamala, Kasase, \& Devlieghere, 2006; Tangni et al., 2003).

The presence of PAT in apples juices commercialized throughout the World indicates that to a certain extent this mycotoxin is

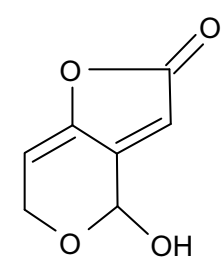

Fig. 1. The chemical structure of PAT. stable to the steps of the apple juice manufacturing process. In order to reduce the contamination of apple juice by PAT, Codex Alimentarius (Codex, 2003b) recommends that the actions be focused on the good agricultural practices (GAP) and good manufacturing practices (GMP) throughout the productive chain of the juice. The Food and Agriculture Organization of the United Nations (FAO, 2003), has also recommended adoption of the Hazard Analysis and Critical Control Points system (HACCP) so as to guarantee the control of PAT and other hazards associated with apple juice.

Diverse techniques and methods have been proposed and studied to control/reduce the level of PAT and the moulds that produce it, during apple juice processing. Thus, the objective of this paper was to revise the influence of the apple juice manufacturing process steps in the control of PAT production, and the increase or reduction of its levels in the final product, by way of a step by step approach. This approach was applied in order to make evident which measures and steps most influenced the control of the mycotoxin in this product.

\section{Overview of apple juice processing}

Ready to drink pasteurized apple juice can be obtained from recently processed fruit or by reconstitution of the concentrated juice to the desired soluble solids content. Fig. 2 presents the flow diagram of the production process and a basic description of the manufacturing steps. It is important to consider that some differences may exist between different industries with respect to the sequence of stages and materials and techniques used. Thus, the objective of this description is to aid the understanding of what occurs in each stage of apple juice processing, and subsequently understand the effect and limitations of the process on the mycotoxin.

After manual or mechanical harvesting, the apples are transported in bins or boxes to the factory or are put into storage. Storage can be carried out in three ways: refrigerated, controlled atmosphere or deck storage, the latter being restricted to industries with a capacity to rapidly process the fruits. Apples should be placed into storage in less than $18 \mathrm{~h}$ after harvest (Codex, 2003b). Tables 1 and 2 present the conditions indicated for the storage of some varieties of apples, under refrigerated or controlled atmosphere conditions. Before entering the storage chambers, antioxidant agents (such as diphenylamine) and fungicides (such as benomyl and benzylmidazoles) are frequently used to avoid physiological and fungal problems (Swindeman, 2002).

After storage, the fruits are transported to the factory, where the contents of the bins or boxes are discharged into water tanks and transported to the washing units. The fruits are washed on belts with the aid of pressurized water sprays to remove residues of soil and foreign matter (Root \& Barret, 2005), and in some cases brushes are used to remove rotten parts and firmly adhered dirt. If the fruits are briefly stored at the factory before processing, this should be for as short a period as possible, not more than $24 \mathrm{~h}$ after their removal from refrigeration (Codex, 2003b). During the selection stage, damaged or rotten fruit can be discarded or partially used by removing the affected parts (Root \& Barret, 2005). Before pressing, the apples are ground to reduce the size of the raw material, so that the pressure in the next stage can be effective. Size reduction is based on the fundamental presupposition of maintaining tissue structure, so that, when pressed, the juice can flow through the ground fruit, which acts as a filter aid to obtain a light, clear product. In the pressing stage, the maximum amount of soluble solids is removed from the ground mass by the use of vertical, horizontal or belt presses (Wosiacki \& Nogueira, 2005), frequently adding ascorbic acid at this stage to avoid enzymatic browning (Rutledge, 1996). Clarification includes an enzymatic depectinisa- 


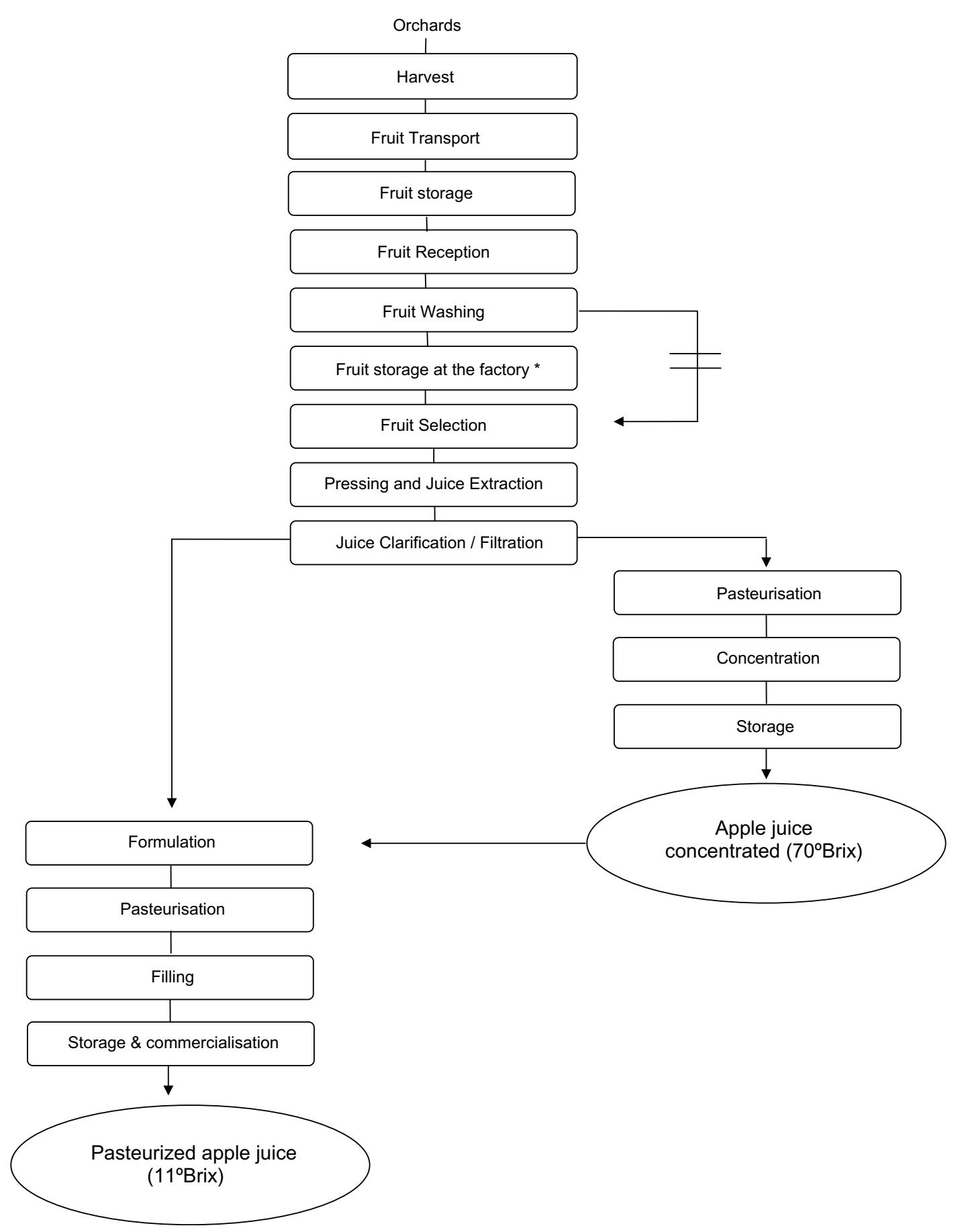

Fig. 2. Apple juice processing steps. ${ }^{*}$ This step is not needed depending on the apple juice directly produced (concentrated or pasteurized).

Table 1

Conditions indicated for the refrigerated storage of some apple cultivars

\begin{tabular}{llll}
\hline $\begin{array}{l}\text { Cultivar - } \\
\text { apples }\end{array}$ & $\begin{array}{l}\text { Optimum temperature } \\
\left({ }^{\circ} \mathrm{C}\right)\end{array}$ & $\begin{array}{l}\text { Relative humidity } \\
(\%)\end{array}$ & $\begin{array}{l}\text { Storage life } \\
\text { (months) }\end{array}$ \\
\hline $\begin{array}{l}\text { Gala (all } \\
\text { strains) }\end{array}$ & 0 & $94-96$ & $4-5$ \\
$\begin{array}{l}\text { Fuji } \\
\text { Golden }\end{array}$ & -1 to 0 & $92-96$ & $6-7$ \\
$\quad 0$ & $94-96$ & $5-6$ \\
delicious & & 95 & 3 \\
Granny smith & 0 & 95 & $3-4$ \\
\hline
\end{tabular}

According to Girardi and Bender (2003), Faragher (2000), and Watkins et al. (2002) tion treatment and finishing, with the removal of compounds (pectic substances, proteins and phenolic compounds) that prejudice the good appearance of the final product (Wosiacki \& Nogueira, 2005).

Enzyme preparations hydrolyze pectic substances responsible for cloudiness (Rutledge, 1996). Refining or finishing can be carried out using materials such as gelatine, silica sol, kaolim, activated carbon, pectic acid, polyvinylpyrrolidone or bentonite (Wosiacki \& Nogueira, 2005), which are mixed with the juice to remove suspended materials resulting from enzyme activity. Clarification is finalised by filtration with the use of filter aids, such as diatomaceous earth, or more recently, by using ultra-filtration (Root \& Barret, 2005; Wosiacki \& Nogueira, 2005). In some industrial plants 
Table 2

Conditions indicated for the storage of some apple cultivars under controlled atmospheres

\begin{tabular}{|c|c|c|c|c|c|}
\hline Cultivar - apple & Temperature $\left({ }^{\circ} \mathrm{C}\right)$ & Optimum $\mathrm{O}_{2}(\%)$ & Optimum $\mathrm{CO}_{2}(\%)$ & Relative humidity (\%) & Storage life (months) \\
\hline Fuji & 1 & 2.0 & 0.5 & 92 & 12 \\
\hline Gala (all strains) & 0 to 0.5 & 1.5 & 1.5 & $92-95$ & 8 \\
\hline Golden Delicious & -0.5 to 2.0 & $1.0-2.5$ & $1.0-4.5$ & $>92$ & $6-10$ \\
\hline Red Delicious & -0.5 to 0.5 & $1-2.5$ & $1-4.5$ & $90-95$ & $6-10$ \\
\hline Granny Smith & -0.5 to 1 & $1-2$ & $0.5-2$ & $90-95$ & $6-11$ \\
\hline
\end{tabular}

Adapted from Girardi and Bender (2003) and Kupferman (2001).

the clarified juice may be destined to pasteurization followed by concentration, whereas in others, after clarification the juice may be directly destined to the formulation of juice or nectar, followed by pasteurization and filling. When a juice is concentrated and stored for use between harvests, it will be submitted to pasteurization twice, the first applied to the juice before concentration and the second to the juice after reconstitution (called the first and second pasteurizations).

The juice is concentrated by evaporation or cry-concentration for between harvest storage and commercialization, preferably concentrating to $70-71^{\circ} \mathrm{Brix}$, and multiple-effect evaporators with aroma recovery units are more commonly used. This is necessary for preserving aroma compounds, which are heat sensible. Although the high acidity and low water activity allow for maintenance of the juice at room temperature (Root \& Barret, 2005), for quality maintenance the juice is usually refrigerated or frozen for storage and commercialization. The formulation stage is used to manufacture nectars, whether using freshly extracted juice or concentrated juice, in this case the formulation is a mixture of juice, sugar and water (Codex, 2005), plus antioxidants such as ascorbic acid and acidulants such as citric acid (Brasil, 1988). When producing apple juice, the concentrated juice is diluted with water, and apple aroma added to the final mixture to avoid losses by evaporation (Lea, 1990). The juice is subsequently de-aerated to avoid browning due to the reaction between dissolved $\mathrm{O}_{2}$ and ascorbic acid (Rutledge, 1996), normally being pasteurized at temperatures between 90 and $98{ }^{\circ} \mathrm{C}$ for a few seconds. After cooling the juice can be packaged in cartons or plastic or glass bottles, these normally being stored and commercialized at room temperature.

\section{The stages of apple juice processing and their effect on PAT}

During the manufacture of apple juice, measures of a physical, chemical, mechanical or biological nature can be used to control or reduce the levels of PAT in the final product. The efficiency of each of these measures can be considered to be dependent on the techniques used and to the training and control given during their application. Of all the stages present in the manufacture of apple juice, only those presenting a recognised effect on the control, increase or reduction of the levels of PAT were described here, as well as those that require more research.

\subsection{Pre-harvest and harvest}

Of the PAT-producing species, Penicillium expansum is probably that most associated with apples and is the cause of the so-called blue rot. Although PAT occurs mostly in mould-damaged fruit, the absence of mould externally visible does not necessarily indicate the absence of the mycotoxin, since fungal growth is not always externally visible. In some cases, internal fungal growth can occur as a result of insect invasion or other types of damage, resulting in the occurrence of PAT in externally undamaged fruit. Even though the spores of many PAT-producing moulds are present on the fruits while on the tree, they do not usually grow before the fruits are harvested. Nevertheless, the growth of these moulds and PAT production can occur post-harvest if they are affected by disease or insect damage or if fruit that fell to the ground are used for processing (Codex, 2003b). This demonstrates the importance of applying good agricultural practices in the stages involved in the pre-harvest of the fruits.

To guarantee the quality of apples used in juice processing, some pre-harvest measures deserve special attention, such as (i) the removal and destruction of rotten fruit or wood; (ii) adequate spacing of the trees to allow for good air and light penetration between them; (iii) the control of pests and diseases that could cause fruit rot or represent a point of entrance for PAT-producing moulds; (iv) the application of fungicides to prevent mould germination and growth during and after harvest; (v) the use of fertilisers based on calcium and phosphorus for the plantation to improve cell structure and reduce the susceptibility to fruit rot; (vi) not store fruit with poor mineral composition for long periods of time (more than 3-4 months), due to their greater susceptibility to physiological disorders and rots, such as those caused by Gloeosporium and Penicillium spp.; (vii) maintain registers of the rot indexes for each orchard, since, to this date, the history of an orchard is the best indication of the need to apply fungicides and of the fruit storage potential (Codex, 2003b).

During harvest, care must be taken so as to avoid fruit damage, independent of whether they are destined for processing, storage and subsequent processing or for the fresh fruit consumer market. Marin, Morales, Hasan, Ramos, and Sanchis (2006) showed the importance of adequate handling aimed at avoiding damaging the apples during the stages prior to processing, observing that the PAT concentration in both portions (decayed and healthy) of the apples was dependent on the diameter of the damaged areas. Thus, the worse the practices before processing, the lower the probability of obtaining a final product within the internationally established limits for this mycotoxin. The non-detection of PAT in juice from apples harvested directly from the trees, and the detection of levels between 40.2 and $374 \mu \mathrm{g} / \mathrm{L}$ in the juice of apples harvested from the ground (Jackson et al., 2003), corroborates the importance of the harvest on final product quality. For mechanically harvested fruits, obtained by shaking the trees and collection from the ground with appropriate machines, certain measures must be taken: (i) remove previously fallen fruit so that only fresh fruit are harvested; (ii) transport of the fruit to the processing plant in up to three days; (iii) cleaning of all transport containers; (iv) separate harvesting of fruit from orchards with high levels of rot, these fruit not being considered for storage; $(v)$ harvesting preferentially during the dry season and placing in bins protected from rain; (vi) fruit selection with rejection of damaged fruit, exposed pulp or showing signs of some disease (Codex, 2003b). Harvesting of the fruits at an adequate maturation stage can greatly reduce the index of rot, since such fruit is firmer and less susceptible to mechanical injury, this being considered the main entry point for Penicillium (Boneti \& Katsurayama, 1998). With the advances of biotechnology, the development of apple varieties more resistant to the attack of pests (insects and fungi) and with firmer skins, leads to the possibility that actions for the control of the production of PAT in post-harvest stages will be more successful. 
The main objective of the selection during harvest is to decrease the incidence of PAT, by excluding fruit with visible signs of rot. If selection is not carried out at this stage, this will result in great increases in PAT during the transport and storage stages. The reduction of visually mouldy apples or showing any form of damage, to levels below $1 \%$ is recommended (FAO, 2003).

\subsection{Fruit transport}

For short distances, the risk of increasing PAT contamination is low, although any physical damage suffered by the fruits during transport, loading and unloading, will increase their susceptibility to subsequent infection by fungi (FAO, 2003).

It is well known that fungi are widely distributed in the environment and the phytopathogenic conidia can survive for long periods in the bins (Little \& Holmes, 2000). Thus, since the pomaceous fruits are generally removed from the bins by discharging with water, followed by long storage periods with prior treatment by immersion or spraying with scald inhibitor and fungicidal solutions, dissemination of $P$. expansum conidia in the sprays or flume water tanks of the fruits can easily occur (Neri, Mari, Menniti, Brigati, \& Bertolini, 2006; Sanderson \& Spotts, 1995; Spotts \& Cervantes, 1986), demonstrating the importance of adopting hygiene measures aimed at controlling contamination by fungi in these systems.

\subsection{Fruit storage}

Throughout the world orchards dedicated exclusively to fruit for processing are non-existent in various countries, and apples not approved by the rigid selection criteria for the fresh fruit consumption market are used for juice processing. Thus, after harvest, the apples may be destined for immediate juice processing or for the fresh fruit market, while another part is destined for storage and subsequent commercialization between harvests. Then, once again between harvests, the fruits rejected by the fresh fruit consumer market quality control, are destined for fruit processing.

P. expansum shows psychrotrophic characteristics, growing and producing PAT under refrigerated storage. With respect to refrigerated storage, Taniwaki, Bleinroth, and De Martin (1989), found that $P$. expansum was capable of producing PAT in apples stored at $25^{\circ} \mathrm{C}$ and at $4{ }^{\circ} \mathrm{C}$ for as long as 20 and 90 days, respectively. A concentration of $310 \mu \mathrm{g} / \mathrm{L}$ was detected after 30 days of storage at $25^{\circ} \mathrm{C}$, while, $300 \mu \mathrm{g} / \mathrm{L}$ was detected after 120 days of storage at $4{ }^{\circ} \mathrm{C}$. Morales, Marin, Rovira, Ramos, and Sanchis (2007a), did not detect PAT after 6 weeks when the fruits were stored refrigerated at $1{ }^{\circ} \mathrm{C}$, despite injury due to mould growth having been observed. $P$. expansum 1071 was capable of growing and producing PAT when the apples were stored in an atmosphere containing $1 \% \mathrm{CO}_{2}, 3 \% \mathrm{O}_{2}$ and $96 \% \mathrm{~N}_{2}$ at a temperature of $0.5{ }^{\circ} \mathrm{C}$ and relative humidity above $90 \%$, the amount of mycotoxin produced being lower when stored under the controlled atmosphere (mean of $0.5 \mu \mathrm{g} / \mathrm{mL}$ ) than when stored only under refrigeration (mean of $2.5 \mu \mathrm{g} / \mathrm{mL}$ ). P. expansum NRRL 973, on the other hand, was only capable of producing PAT (mean of $3.0 \mu \mathrm{g} / \mathrm{mL}$ ) when the apples was stored under refrigeration without the controlled atmosphere (Lovett, Thompson, \& Boutin, 1975), demonstrating diversity between different $P$. expansum strains and their capacity to produce PAT in apples stored under a controlled atmosphere. In a more recent study, some strains of $P$. expansum were able to grow and produce PAT at $0^{\circ} \mathrm{C}, 3^{\circ} \mathrm{C}, 6^{\circ} \mathrm{C}$, $17{ }^{\circ} \mathrm{C}$ and $25^{\circ} \mathrm{C}$, but not when the atmosphere contained $3 \% \mathrm{CO}_{2} /$ $2 \% \mathrm{O}_{2}\left(25^{\circ} \mathrm{C}\right)$. With $3 \% \mathrm{CO}_{2} / 10 \% \mathrm{O}_{2}$ and $3 \% \mathrm{CO}_{2} / 20 \% \mathrm{O}_{2}$, mycotoxin production occurred, demonstrating that the $\mathrm{CO}_{2} / \mathrm{O}_{2}$ ratio must be maintained throughout the storage period, since any increase in the $\mathrm{O}_{2}$ concentration can be followed by the production of PAT by some species of fungi (Paster, Huppert, \& Barkai-Golan, 1995).
Since fruits may be stored for up to 12 months before processing, it was concluded that, depending on the storage conditions (refrigeration or controlled atmosphere) and the varieties, the greater the percentage of damaged fruit in a stored batch, the greater the amount of PAT in the derived products.

Space or financial limitations for refrigerated and/or controlled atmosphere fruit storage, can lead to deck storage for considerable periods of time (Sydenham et al., 1995), resulting in serious implications in the levels of PAT. In their study, Sydenham et al. (1997) showed that the concentration of PAT in deck stored apples increased with storage time. A mean concentration of $90 \mu \mathrm{g} / \mathrm{mL}$ was obtained after 7 days of storage, $395 \mu \mathrm{g} / \mathrm{mL}$ after 15 days of storage and $2445 \mu \mathrm{g} / \mathrm{mL}$ after 33 days of storage, the rotten portions of the fruits containing an average of $1120 \mu \mathrm{g} / \mathrm{mL}, 2525 \mu \mathrm{g} /$ $\mathrm{mL}$ and $6235 \mu \mathrm{g} / \mathrm{mL}$, respectively, after 7,15 and 33 days of storage, indicating that the longer the storage time, the greater the probability that the amounts of PAT exceed the limits in the final product. The storage of apples before processing is a critical control point in apple juice processing, a critical time limit of $48 \mathrm{~h}$ being considered adequate to control the accumulation of PAT in this product (FAO, 2003). Although Morales, Marín, Centelles, Ramos, and Sanchis (2007b) found that the accumulation of PAT only significantly increased after $48 \mathrm{~h}$ of storage at $20^{\circ} \mathrm{C}$ (simulating deck storage), they recommended that this critical limit be changed depending on the quality of the fruit and other factors such as the temperature and moisture conditions, when using deck storage. Considering that the time the fruits are maintained at room temperature is more important for the accumulation of PAT than the post-harvest treatments (Morales, Sanchis, Rovira, Ramos, \& Marin (2007), is recommended that this type of storage be reduced as much as possible. However, considering that it is frequently impossible to harvest the fruits and process them immediately, the assessment of their quality before storage is indicated as the principle measure to prevent the accumulation of this mycotoxin (Morales et al., 2007b).

Since storage under refrigeration and controlled atmosphere alone fail to impede fungal growth and PAT production, other additive treatments have been studied, including the application of fungicides. The application of benzylmidazol-based fungicides and of organo-phosphorated insecticides (Draughon \& Ayres, 1980) was abandoned for reasons of safety and fungal adaptation. Morales et al. (2007a), reported that the efficiency of a mixture of folpet and imazalil (agents commonly used to prevent blue rot in packing houses) depends on the maturity of the fruit, only showing an effect in controlling damage with mature fruits. Besides they found that the accumulation of PAT was independent of the application of fungicide during the pre-storage period, suggesting that the time the apples spent at room temperature before refrigerated storage was critical with respect to the production of mycotoxin. This study confirms the additive effect of applying fungicides with that of storage under refrigeration and controlled atmosphere.

Errampali (2004) \& Errampali et al. (2005) used the fungicide fludioxinil both as a preventative treatment and in the treatment of apples already infected with $P$. expansum. According to Neri et al. (2006), vapours of trans-2-hexenal (an aroma component of many fruits and vegetables), with a concentration of $12.5 \mu \mathrm{gL} / \mathrm{L}$ showed a potential for the control of blue rot, the PAT content and apple quality in Golden Delicious apples. Also vapours of trans-2-hexenal, showed curative activity with a significant reduction in infection by $P$. expansum. However, according to the variety of apple, variable responses were observed with respect to phytotoxic symptoms, the development of off-flavours, fungicidal activity and the control of PAT production.

Restrictions with respect to the toxicity of fungicides and the development of fungal resistance to them have stimulated a search for alternative control agents, such as sanitizers, natural or biolog- 
ical agents or a combination of the two. Hasan (2000) obtained complete inhibition of growth and damage at $25{ }^{\circ} \mathrm{C}$ in apples infected by Aspergillus alternata, Aspergillus flavus, Aspergillus niger, Cladosporium cladosporioides, Fusarium sp., P. expansum and Rhizopus stolonifer, by immersion in a $3 \%$ sodium hypochlorite solution for $5 \mathrm{~min}$. Chen, Ingham, \& Ingham (2004) reported that 2-5\% acetic acid solutions were effective at inhibiting the growth of $P$. expansum and PAT production. For industrial application, if the contact time is guaranteed, the apples can be immersed in a $2 \%$ solution in a tank, whereas with a $5 \%$ solution, the application is made using sprays, in both cases without subsequent rinsing before storage. Despite a lack of data proving the efficiency of these agents during fruit storage, the data indicate they can be considered as a safer and cheaper alternative to prevent or control the production of PAT during the period after removal of the fruits from refrigeration until they are processed. Using the hurdle technology concept and considering that the fruits are stored for up to 12 months (depending on the variety and conditions) before processing, a combination of disinfection of the fruits with acetic acid before storage and subsequent treatment with a low concentration of fungicide (which shows more prolonged activity), appears to be a promising alternative when large amounts of apples are to be stored.

Hasan (2000) studied the use of agents naturally present in foods, attaining complete inhibition of the production of PAT by $P$. expansum using $0.2 \%$ lemon essential oil. $90 \%$ inhibition was obtained using $0.05 \%$ and $0.2 \%$ of lemon and orange essential oils, respectively. Calvo, Calvente, Orellano, Benuzzi, \& Tosetti (2007) obtained the biological control of post-harvest deterioration by $P$. expansum and Botrytis cinerea in apples using the bacteria Rahnella aquatilis, which was capable of causing varied reductions in the incidence and severity (mean diameter of the damage) of the disease caused by these microorganisms at $28^{\circ} \mathrm{C}, 15^{\circ} \mathrm{C}$ and at $4{ }^{\circ} \mathrm{C}$, in addition to completely inhibiting the in vitro germination of the fungi. A combination of heat treatment, calcium infiltration and biological control (Pseudomonas syringae) was shown to be efficient in the control of the growth of $P$. expansum in apples (Conway, Janisiewicz, Klein, \& Sams, 1999).

Although some previously described techniques have been effective in reducing the incidence of blue rot and PAT, the majority show limitations with respect to cost and/or practical applicability. One alternative that avoids the application of any agents to the fruits, also being cheaper, easier to apply and controlling the production of PAT and the growth of $P$. expansum during storage and transport, is the storage of the apples in polyethylene (PE) packages, with or without a modified atmosphere, according to Moodley, Goviden, \& Odhav (2002). They observed that the PE package was capable of reducing PAT production by $99.5 \%$ and fungal growth by up to $68 \%$ in relation to non-packaged apples, even without the use of a modified atmosphere, during storage at $25{ }^{\circ} \mathrm{C}$ for 14 days, appearing to be an alternative to the use of fungicides for the storage of fruits. With a modified atmosphere of $88 \%$ $\mathrm{CO}_{2} / 12 \% \mathrm{~N}_{2}$, the amount of PAT produced was reduced by up to 99.97\%.

Jackson et al. (2003) showed the importance of the quality of the fruit as from the harvest, avoiding the use of those picked up from the ground, of a careful selection for processing, and of the influence of the storage stage on the final quality of the apple juice. These authors reported that when the fruits were stored at $0-2{ }^{\circ} \mathrm{C}$ for 46 weeks, no PAT was found in the juice when the apples were submitted to a careful selection before storage, but levels from 0.97 to $64.0 \mu \mathrm{g} / \mathrm{L}$ were detected in juice pressed from unculled apples that were maintained under the same conditions. Levels of PAT between 0 and $15.1 \mu \mathrm{g} / \mathrm{L}$ and between 59.9 and $120.5 \mu \mathrm{g} / \mathrm{L}$ were found in the juice from selected and non-selected fruits, respectively, when controlled atmosphere storage (unspecified conditions) was used.
In order to maintain good internal and external fruit quality, the regular functioning of the cold chambers must be assured by periodical inspections of the refrigeration and gas control (controlled atmosphere) equipments (Girardi \& Bender, 2003). Besides, cold chambers hygienic conditions should be assured. Their disinfection can be carried out by washing with detergent and pressurized hot water, followed by disinfection by spraying with a sodium hypochlorite solution $(0.025 \%)$, sodium sulphamide chlorine paratoluene $(0.015 \%)$ or thermo-atomisation with chlorohexadine digluconate (0.02\%) (Sanhueza, 1996). Carrying out monthly quality control laboratory analyses (total soluble solids, pulp firmness, acidity) and maturation tests of 20-50 fruits, internal and external quality of the fruits can be determined. These analyses allow for a prognosis of the potential duration of the conservation period, provide information for evaluating the evolution of quality problems observed at the start of storage, allow for observing the reaction of the fruits under the storage conditions and it can also be verified the behaviour of different cultivars or batches with respect to the external characteristics of maturation (wilting, rotting, physiological disorders) (Girardi \& Bender, 2003). Thus, if well established storage conditions are not adopted, large amounts of mycotoxin may be produced and subsequently be present during the later stages of juice industrialisation.

\subsection{Fruit reception}

Monitoring of fruit quality during reception can be considered as the first control measure of PAT effectively applied by the juice processing industry.

The reception of batches with the lowest possible amount of rotten fruit is of extreme importance in order to avoid contamination of healthy fruit. According to FAO (2003), in this stage, apple batches of inferior quality (high proportion of damaged or rotten fruit), should not be accepted for processing due to the elevated concentrations of mycotoxin probably present in such batches. This is required since it would be very difficult to hand select apples from a batch containing an average of more than $10 \%$ rotten fruit, and still attain an acceptable level of PAT in the final product.

\subsection{Fruit washing}

Sydenham et al. (1995) obtained a significant reduction in the levels of PAT during the washing stage of deck-stored apples, reporting a mean reduction in the mycotoxin from $920 \mathrm{ppb}$ to $190 \mathrm{ppb}$ (reduction of approximately 80\%). In 1997, Sydenham et al. observed that the amount of PAT in non-processed deckstored fruit reached $90 \mathrm{ppb}$ after 5 days, $395 \mathrm{ppb}$ after 15 days and $2245 \mathrm{ppb}$ after 33 days, but decreased to values of $75 \mathrm{ppb}$, $100 \mathrm{ppb}$ and $695 \mathrm{ppb}$, respectively, after the washing stage. Acar, Gökmen, \& Taydas (1998) reported that washing with highly pressurized water was capable of reducing the levels of PAT by 10$100 \%$, depending on the initial amount of mycotoxin in the apples. The efficiency of the washing solution used (tap water, tap water with $100 \mathrm{ppm}$ or $200 \mathrm{ppm}$ active chlorine) was also affected by the initial PAT level of the fruits, an initial mean contamination level of $20 \mu \mathrm{g} / \mathrm{L}$ being reduced to mean levels of $5 \mu \mathrm{g} / \mathrm{L}$ in the juice. When the apples were highly contaminated (approximately $350 \mu \mathrm{g} / \mathrm{L}$ ), washing was incapable of reducing the PAT levels to below $50 \mu \mathrm{g} / \mathrm{L}$, independent of the type of solution used.

Due to the various limitations of the use of chlorinated agents in the control of post-harvest pathogens (sensibility to organic matter and high corrosive power) (Chen et al., 2004), the choice and application of other complementary agents in the washing of fruits and their effect on PAT, is still an interesting field of study. In this way, the use of electrolyzed oxidizing water (EO) has a potential as an alternative to chlorine disinfectants for minimizing post-harvest 
infection of apples in dump tanks and other recirculation water systems. Although, a possible limitation to the large-scale use of this technique is the cost associated with equipment and electrical consumption (Okull \& Laborde, 2004). Thus, studies with other complementary washing agents should be based not only on their efficiency, but also on questions such as cost, practical applicability (safety and corrosive power) and contamination of the environment by derived residues.

Although a washing stage with pressurized water can be considered as a good measure in the control of PAT, it is insufficient to completely eliminate the toxin, since it is only capable of removing the rotten parts of the fruit (Marin et al., 2006). In this stage, a reduction in the fungal population has also been reported (Sydenham et al., 1995, 1997), which can result in a lesser formation of damage and rot during storage or between washing and pressing in the factory. On the other hand, since the washing stage disturbs the rotten areas, it can result in the suspension and dispersion of PAT and fungal spores in the washing water (Sydenham et al., 1995). If the hygiene of the installations and the air is not carefully monitored and assured, aerosols created during washing could lead to an increase in the risk of fungal proliferation.

\subsection{Fruit storage at the factory}

Ideally, the apples should be maintained under refrigeration $\left(<10^{\circ} \mathrm{C}\right)$ throughout storage at the factory until processed. When refrigerated storage is not possible, room temperature storage should not be for more than $48 \mathrm{~h}$ (FAO, 2003). The adoption of these measures should be considered adequate to control rotting and the consequent production of PAT, based on the study of Morales et al. (2007a), who studied PAT formation in Golden Delicious apples as a function of storage time. They reported that even after prior storage at $1{ }^{\circ} \mathrm{C}$ for 6 weeks, PAT was only detected (in amounts varying from $10.821 \mathrm{ng}$ to $30.602 \mathrm{ng}$ per apple) after maintaining the fruits at $20^{\circ} \mathrm{C}$ for 3 days (simulation of the time interval that apples can be maintained at room temperature before processing). However, more work is needed to confirm the results of this study with other apple varieties.

\subsection{Fruit selection}

The efficiency of fruit selection within the factory and consequent reduction of PAT in the final product, can be considered to be dependent on the combined efficiency of all the selection operations carried out previously. This dependency is explained since an increase in the number of fruits with rotten parts in the stages prior to pressing, reduces selection efficiency. Apple selection in the factory can be done by exclusion and discarding of the fruits showing any damage or by the conditional use of unaffected parts.

The amount of PAT in the juices can be reduced from a mean concentration of $190 \mathrm{ppb}$ (after washing) to $55 \mathrm{ppb}$ after removal of the rotten or damaged fruit. An average concentration of $2335 \mathrm{ppb}$ has been detected in the rotten parts of apples (Sydenham et al., 1995). In another study, Sydenham et al. (1997) managed to reduce the amount of PAT in deck stored fruits by removing rotten or damaged fruit, from $75 \mathrm{ppb}$ (after washing) to $55 \mathrm{ppb}$ (after selection). A reduction from $100 \mathrm{ppb}$ (after washing) to $90 \mathrm{ppb}$ (after selection) after 15 days of storage and from $695 \mathrm{ppb}$ (after washing) to $405 \mathrm{ppb}$ (after selection) after 33 days of storage were obtained. Levels of up to $6235 \mathrm{ppb}$ were found in the rotten parts of fruits after 33 days of storage. The presence of rotten parts on the fruits (increase of $1.76 \%$ on the 15 th day to $3.2 \%$ on the 33 rd day), was followed by a numerical increase in the levels of PAT and by an increase in the amount of material discarded.

Trimming is the separation of defective tissue from healthy tissue, a process used commercially so as to maximise the use of fruits and vegetables. Trimming is capable of reducing the total PAT present in apples from 93\% to 99\% (Lovett et al., 1975) and is used due to the great economic loss caused by discarding the whole fruit when attacked by fungi. Although the presence of damage caused by $P$. expansum does not necessarily imply the presence of PAT, the mycotoxin can be present in small amounts in some uninjured parts or in areas near injured parts (Taniwaki, Hoenderboom, Vitali, \& Eiroa, 1992). Normally, an increase in the diameter of an injury is accompanied by an increase in its depth (Marin et al., 2006). Thus, diffusion of the mycotoxin into the healthy parts of the fruit appears to make it impossible to eliminate it completely (Laidou, Thanassoulopoulos, \& Liakopoulou-Kyriakides, 2001). Beretta et al. (2000) analysed apples with damaged areas and determined the PAT concentrations in these and the unaffected parts. In the 21 samples of non-damaged areas with the skin, the toxin was found in $17(81 \%)$ at a maximum level of $1170 \mu \mathrm{g} / \mathrm{kg}$, and after peeling, the mycotoxin was still detected in 7 (33\%) of the samples, at a maximum level of $93 \mu \mathrm{g} / \mathrm{kg}$. These results show that even if these parts are removed, the amount of PAT can still exceed the internationally established safe limits. Martins, Gimeno, Martins, \& Bernardo (2002) analysed 352 samples of different varieties of apple with from $25 \%$ to $42 \%$ damaged areas, and found no correlation between the amount of PAT and the size of the damaged area, but dissemination of the mycotoxin to the undamaged parts was always observed, with the larger amounts being found in the parts adjacent to the damaged or rotten areas. Taniwaki et al. (1992) reported that the largest amounts of PAT were found within $1 \mathrm{~cm}$ of the damaged area, the amounts decreasing the further one penetrates into the fruit. In their study, Rychlik \& Schieberle (2001) showed that no mycotoxin was detected at a distance of $2 \mathrm{~cm}$ from an area infected by $P$. expansum. Of the factors that could affect the amount of diffusion of PAT in Golden Delicious and Fuji apples, variety and acidity appear to be the most important. More acid softer apples such as Golden Delicious, allow for a greater production of PAT, while those of the variety Fuji allow for greater diffusion of the mycotoxin. In addition, the diameter of the damaged area and the degree of fruit maturity can also affect the amount of PAT produced by the fungus (Marin et al., 2006). As only two apple varieties of apples were studied, more research is necessary on factors affecting PAT diffusion for consistent conclusions.

The lack of evidence that PAT can diffuse throughout the apple tissue indicates that trimming between 1 and $2 \mathrm{~cm}$ around the rotten areas can eliminate most of the toxin from the fruit. Nevertheless, the decision to trim or to discard should be based on the size of the rotten area and on the size of the fruit (Rychlik \& Schieberle, 2001; Taniwaki et al., 1992). According to Kadakal \& Nas (2002b) in general, the PAT concentration in the apple juice samples increased with increasing the decay proportion in the surface of apples. PAT concentrations in all apple juice samples produced from sound apples were less than $50 \mathrm{ppb}$, while apple juice samples produced with the $30 \%, 60 \%$ and $100 \%$ decayed apples were over $50 \mathrm{ppb}$. Thus, apples which are decayed more than $30 \%$ in its surface should not be used for the production of safe patulin-free apple juice, it being important and preferable to prevent the accumulation of mycotoxin than try to remove it from the raw materials (Morales et al., 2007a).

Although the majority of infections by $P$. expansum in apples are due to injuries caused by insects and by precarious transport conditions, they can also be caused by penetration of the fungus via the pedicel vascular system, the calycine sinus and the lenticels (Neri et al., 2006).

However, the lack of studies to determine the incidence of internal rot in the apple varieties used in industrial processing and the variables that can affect the rate of incidence, make it impossible to evaluate the impact on the level of PAT in the final product. If all the pre-harvest, harvest and storage practices are 
adequately applied, the reason for the prevalence of PAT in apple juice is internal rot. The Codex Alimentarius recommends that fruit varieties with an open calyx should be examined for internal rot by a regular check before pressing, due to their greater susceptibility to internal fungal infections (externally appearing to have no infection). A sample of each batch of fruits should be examined, cutting through the middle and searching for signs of mycelial growth. If the frequency of fruits showing internal rot passes the level considered admissible for juice processing, the batch should be rejected (Codex, 2003b).

\subsection{Juice pressing, clarification and filtration}

The removal of PAT from culture media using activated carbon (Karow \& Foster, 1944) stimulated (Sands, McIntyre, \& Walton, 1976) to study the use of granulated activated carbon to remove the mycotoxin from apple juice. Both stirring for $30 \mathrm{~min}$ with activated carbon $(5-20 \mathrm{mg} / \mathrm{mL})$ and filtering through activated carbon (40-60 mesh) were capable of reducing the levels of PAT by between $98.15 \%$ and $100 \%$ in the apple juice. Kadakal \& Nas (2002a) evaluated the effect of adding 0.5, 1.0, 1.5, 2.0, 2.5 and $3.0 \mathrm{~g}$ activated carbon per litre of apple juice containing $62.3 \mathrm{ppb}$ PAT, followed by stirring for $5,10,20$ and $30 \mathrm{~min}$. They concluded that $3 \mathrm{~g} / \mathrm{L}$ of activated carbon and stirring for $5 \mathrm{~min}$ was the most effective treatment to reduce PAT in the juice (reduction to $30.8 \mathrm{ppb}$ ), an increase in clarity, reduction in colour and slight reductions in the fumaric acid content, $\mathrm{pH}$ and ${ }^{\circ}$ Brix of the juice also being observed. Leggott, Sheppard, Stockenström, Staal, \& van Schalkwyk (2001) obtained a reduction in PAT of between $20 \%$ and $80 \%$ of the initial amount in apple juice after adsorption onto activated carbon, the variation in percent reduction depending on the type of carbon, type of activation (physical or chemical) and the juice solids content. In a Turkish factory, Kadakal, Sebahattin, \& Poyrazoglu (2002) obtained an average reduction of PAT content of $22.9 \%$ in apple juice using activated charcoal treatment. They showed that in commercial processing conditions depending of initial mycotoxin content, the legal limit ( $50 \mathrm{ppb}$ ) could not be achieved.

Mutlu \& Gökmen (1998) studied the use of a recycling system for the adsorption of PAT from apple juice. The treatment was capable of reducing the initial levels of PAT in the juice by up to $99 \%$, but markedly altered the quality as well, indicating the need for further studies for a better design and optimisation of the activated carbon columns, so as to reduce the levels of PAT without altering the quality of the juice. Huebner et al. (2000) developed a composite of adsorbent carbon (CAC) (ultra-fine active carbon bonded to granulated quartz), and studied its efficiency in reducing the levels of PAT in an aqueous solution and in apple juice, but although capable of reducing the levels of PAT in these solutions, the process using CAC led to changes in product appearance and flavour. Apart from these disadvantages, one should also consider the environmental impact due to the generation of an excess of residues by the application of activated carbon (Gökmen, Artik, Acar, Kaharaman, \& Poyrazoglu, 2001). Since the treatment with activated carbon represents a substantial increase in costs for the industry and considering that its efficiency depends on the time that passed before its use, it is important to evaluate and verify the efficiency of the different types of activated carbon available for the removal of PAT (Leggott et al., 2001). Gökmen et al. (2001) showed that the clarification with activated carbon caused alterations in the colour and phenolics content and reduced the levels of PAT by up to $40.9 \%$, whereas a resin based on DVB (polystyrene divinyl benzene) was capable of reducing the PAT levels by $11 \%$. The use of other synthetic polymers was able to reduce the levels of PAT in apple juice by more than $45 \%$ (Canãs \& Aranda, 1996).
A procedure for reducing the PAT content in fruit juices, which includes the use of a resin having an abundance of micropores of less than $20 \AA$ minimum pore width and a pore surface capable of retaining PAT by chemisorption forces, was developed and patented by Miller \& Lyndon (2001). Basically, the process consists of passing the juice through the resinous material for various cycles followed by regeneration of the resin. This step involves the conversion of the PAT held by the resin into a more easily flushed out derivative, using ammonia or a volatile base, preferably generated in situ from a high $\mathrm{pH}$ solution. The process patented is capable of reducing the levels of PAT in the juice by more than $85 \%$ and shows as its principle advantages the fact that it does not generate environmental problems (since the resin regeneration process inactivates the mycotoxin contained in the residues), or involve the costs associated with the use of active carbon.

Some conventional clarification techniques have been considered efficient in the reduction of PAT. Depectinisation, clarification and filtration using a rotary vacuum pre-coat filter can reduce the levels of PAT by $39 \%$, while the use of depectinisation and clarification and a gelatine/bentonite mixture, followed by ultra-filtration, reduced the mycotoxin level by $25 \%$ (Acar et al., 1998). Bissessur, Permaul, \& Odhav (2001) evaluated the effect of various conventional techniques on the reduction of PAT levels during the clarification stage of apple juice, and reported that centrifugation was the most efficient treatment tested, with a reduction in PAT of $20.5 \%$. Refining with bentonite was the second most efficient with a reduction of $8.5 \%$ in the levels of the toxin. Filtration with diatomaceous earth and enzyme treatment (pectinase) were the least effective methods of those evaluated, only reducing the PAT levels by $3 \%$ and $4.5 \%$, respectively. The combination of centrifugation and refining with bentonite caused a $20.5 \%$ reduction of PAT, while the combination of centrifugation with enzyme treatment reduced the mycotoxin by $17 \%$, since the pectin molecules present in the juice were degraded by the enzymes, reducing the efficiency of centrifugation. The least efficient combinations were refining with bentonite plus filtration with diatomaceous earth, and filtration with diatomaceous earth plus enzyme treatment, with reductions in PAT of $12 \%$ and $7.5 \%$, respectively. In general the lower values obtained using combined methods could be explained by the fact that removal of PAT depends mostly on bonding of the PAT to particulate material, which was removed in the clarification step. The processes described above presented advantages with respect to their simplicity for implementation, and were cost effective and did not require long periods of time or much work. However, the possibility of producing centrifugation by-products (for example cake press) with high levels of PAT is a cause for concern for the industries, making the use of such by-products for animal feed non-viable.

Beyond the effect in the PAT content of apple juice, the clarification/filtration step can be considered an important way to control the contamination of final product by heat resistant fungi and a possible PAT production in the packages. According to King, Michener, \& Ito (1969), the filtration of fruit juice with diatomaceousearth filters (a common processing step) can result in reduction on the order of $99.999 \%$ in count of experimentally added ascospores and ascis of Byssochlamys fulva. This step can be considered as a critical control point (CCP) if the main is avoids the possibility of PAT production in the final products by these fungi.

\subsection{First pasteurization}

Controversial results have been obtained for the studies evaluating the effects of pasteurization on the levels of PAT in apple juice. The heat stability of this mycotoxin was first reported by Wiesner (1942) in aqueous solution. Heatley \& Philpot (1947) subsequently reported that PAT was stable to a heat treatment of 
$100{ }^{\circ} \mathrm{C} / 15$ min at pH 2.0 in a model system. Scott \& Somers (1968) reported that the heating of apple juice containing added vitamin $\mathrm{C}$ (ascorbic acid) $(35 \mathrm{mg} / 100 \mathrm{~mL})$ at $80^{\circ} \mathrm{C}$ for $30 \mathrm{~min}$ for 10 and 20 min caused a reduction in the initial amount of PAT $(200 \mu \mathrm{g})$ of $45 \%(90 \mu \mathrm{g})$ and $55 \%(110 \mu \mathrm{g})$, respectively. In addition, Kubacki (1986) reported that PAT was stable to heating at $80^{\circ} \mathrm{C}$ for $30 \mathrm{~min}$, reductions greater than $20 \%$ of this mycotoxin only occurring when the juice was heated at $120{ }^{\circ} \mathrm{C}$ for $30 \mathrm{~min}$. A residual level of $67 \%$ PAT was recovered from apple juice heated at $120^{\circ} \mathrm{C}$ for $177 \mathrm{~min}$ (Kryger, 2001), whereas Taniwaki et al. (1989) submitted apple juice contaminated with PAT $(1500 \mu \mathrm{g} / \mathrm{L})$ to heating at $90{ }^{\circ} \mathrm{C}$ for 2 min, followed by hot-filling and a final 5-min heat treatment in boiling water followed by cooling to room temperature, and observed a $60 \%$ reduction in the PAT levels. More recently, Kadakal \& Nas (2003) investigated the effect of heating at $90^{\circ} \mathrm{C}$ and $100{ }^{\circ} \mathrm{C}$ for $5,10,15$ and 20 min on the colour, clarity, and hydroxymethylfurfural (HMF) and PAT levels in apple juice. HMF is an intermediate product in the formation of brown pigments during the Maillard reaction between hexoses and amino components, occurring during processing (mainly heating) and storage of fruit juices and other foods. In fresh unheated juices, the HMF content is practically zero, which enables to this substance to be used as chemical marker in acidic foods (Gentry \& Roberts, 2004). HMF also contributes (often significantly) to background noise during chemical analysis of PAT. Heating at $90{ }^{\circ} \mathrm{C}$ and $100{ }^{\circ} \mathrm{C}$ resulted in significant reductions in the PAT levels, the reductions increasing with increase in treatment time, and being quicker in the first 5 min of treatment, followed by a reduction in the degradation velocity. Treatments at $90^{\circ} \mathrm{C}$ and $100{ }^{\circ} \mathrm{C}$ for $20 \mathrm{~min}$ caused $18.81 \%$ and $25.99 \%$ reductions in PAT, respectively, while, maximum mean values for HMF of $8.91 \mathrm{mg} / \mathrm{L}$ and $10.14 \mathrm{mg} / \mathrm{L}$ were obtained for the same treatments. Small changes in the colour and clarity of the apple juice were related to the increase in HMF content, which was affected by the heating time and temperature. Despite not representing the conditions currently used in industries for the heat treatment of juices, these studies demonstrated the heat stability of PAT to various time/temperature binomials. Thus, these studies showed that if the contamination is high in the initial processing stages, it will be practically impossible to obtain significant reductions in the level of the mycotoxin in the final product.

Lovett \& Peeler (1973) were the first to describe the kinetic parameters of the heat inactivation of PAT. The authors determined the kinetic parameters for the heat inactivation of this mycotoxin in Mcllvaine's buffer (a buffer composed by citric acid and sodium phosphate) observing elevated heat resistance at the three values of pH studied: $3.5,4.5$ and 5.5. The $D$ (time to cause one logarithmic cycle reduction in a microbial population at a determined temperature) value reduced as the $\mathrm{pH}$ increased, corroborating the greater heat stability of the mycotoxin in acid environments. The $D$ values at $105^{\circ} \mathrm{C}, 110^{\circ} \mathrm{C}, 115^{\circ} \mathrm{C}, 120^{\circ} \mathrm{C}$ and $125^{\circ} \mathrm{C}$ in solution at $\mathrm{pH} 3.5$ were respectively 1058, 744, 527, 378 and $268 \mathrm{~min}$. In solution at $\mathrm{pH} 4.5$, the $D$ values were respectively $695,444,334$, 236 and $167 \mathrm{~min}$, while in solution at pH 5.5 the values found were $167,109,71,48$ and $33 \mathrm{~min}$, respectively. The reported $Z$ values $\left({ }^{\circ} \mathrm{C}\right.$ ) (variation in the temperature required for a reduction of $1 \log$ arithmic cycle in the $D$ value) were $33.4^{\circ} \mathrm{C}$ at $\mathrm{pH} 3.5,31.6^{\circ} \mathrm{C}$ at $\mathrm{pH}$ 4.5 and $27.7^{\circ} \mathrm{C}$ at $\mathrm{pH}$ 5.5. An average reduction of PAT content in the apple juice after heat treatment $\left(90^{\circ} \mathrm{C} / 10 \mathrm{~s}\right)$ in a Turkish factory $13.4 \%$ (reduction of $96.5 \mathrm{ppb}$ before heat treatment to 83.6 ppb after it) (Kadakal et al., 2002). Wheeler, Harrison, \& Koehler (1987) compared batch pasteurization processes $\left(90^{\circ} \mathrm{C}\right.$ for $10 \mathrm{~min}$ ) with high temperature-short time (HTST) processes $\left(60{ }^{\circ} \mathrm{C}, 70^{\circ} \mathrm{C}, 80^{\circ} \mathrm{C}\right.$ and $90^{\circ} \mathrm{C}$ for $10 \mathrm{~s}$ ) and their effects on the levels of PAT in apple juice. They obtained significant reductions, the HTST treatment at $90^{\circ} \mathrm{C} / 10 \mathrm{~s}$ reducing the level of mycotoxin initially present in the juice by $19 \%$, showing that equivalent indus- trially applied processes do not assure its elimination. With the need to apply higher time/temperature binomials due to the occurrence of the spoilage of apple juice by Alicyclobacillus spp. (Cerny, Hennlich, \& Poralla, 1984) the determination of destruction kinetics of PAT in apple juice and nectar under non-isothermal conditions (continuous systems), would result in obtaining more realistic parameters, and continues to be a necessary study. More research is needed to determine the thermal stability of PAT in apple juice as a function of suspended (insoluble) solids content.

Despite the studies showing no significant reduction in the amount of PAT in apple juice after pasteurization, the destruction of the spores of $P$. expansum reduces the risk of the subsequent production of this mycotoxin (FAO, 2003) and also the risk of Escherichia coli 0157:H7 and Cryptosporidium parvum infections related to apple juice consumption (CDC, 1996, 1997). However, it is important to consider that in some parts of the world there may be a significant demand for the production and consumption of fresh, non-pasteurized apple juice. A probable production of PAT after the pasteurization stage (storage/commercialization) allows for the establishment of two possible scenarios, based on the fungi and the manufacturing processes involved. The first considers the non-pasteurized apple juice, which, due to its lack of pasteurization, could allow the growth of psychrotrophic species of $P$. expansum during the storage and commercialization of the product, with the production of PAT. Due to the absence of any heating stage, activation of the ascospores of heat resistant fungi (Byssochlamys nivea, for example) is unlikely, and from the low counts of these microorganisms in the juices, their importance as possible deteriorative agents and PAT producers appears to be marginal in this case. However, the probability of producing PAT by species of heat resistant fungi surviving to apple juice heat process, during the storage of pasteurized juice remains obscure (second scenery).

\subsection{Concentration}

A study of the effect of the concentration stage on the PAT content is important, since this unit operation is widely used, mainly to reduce costs and storage space for commercialization. Kubacki (1986) reported a $24 \%$ reduction in the PAT levels present in apple juice, the majority being removed by concentration using vacuum distillation. This reduction was rather due to time and temperature exposition and a probable PAT transformation into a substance no longer identifiable as such mycotoxin, than due to PAT removal to volatile phase. Kadakal \& Nas (2003) studied the effect of the concentration stage (evaporation) at $70^{\circ} \mathrm{C}$ and $80^{\circ} \mathrm{C}$ for $5,10,15$ and 20 min on the PAT and HMF levels and on the colour and clarity of apple juice. They showed reductions in the levels of PAT as the evaporation time and temperature increased, the highest mycotoxin degradation rates being observed after $15 \mathrm{~min}$ of evaporation. The treatments at $70{ }^{\circ} \mathrm{C}$ and $80{ }^{\circ} \mathrm{C}$ resulted in reductions of $9.4 \%$ and $14.06 \%$, respectively, in the concentrations of PAT after $20 \mathrm{~min}$. Evaporation caused a greater reduction in the clarity and colour of the juice than the heat treatment stage. Although the levels of HMF increased with evaporation time, reaching maximum values after $20 \mathrm{~min}$, this increase was greater during the heat treatment than during evaporation. In a study on the effects of some of the stages of apple juice processing, Leggott et al. (2000) obtained no reduction in the levels of PAT during the concentration stage collecting samples in a factory. This confirms that processing conditions and other factors such as equipments, can lead to discrepancies in relation to the reduction in the levels of PAT when compared to data obtained in a laboratory, where the conditions are much better controlled.

The aroma of commercial apple juice is composed mostly of water with a small percentage of alcohol and levels in parts per million (ppm) of various aromatic compounds, representing the 
most volatile fraction of the juice. The aroma of apple is an important product of the concentration of apple juice, and is added back to the juice to reconstitute its natural flavour, also being used as a flavouriser in other food applications. Kryger (2001) showed a reduction in the level of PAT in the distillate of apple juice, by a factor of at least 250 as compared to the levels found in the original juice. Due to the fact that PAT is less volatile than water, it is not volatilized during the concentration stage, and is therefore not present in apple aroma, although it may still be present in the concentrated juice. Thus, it is important to consider that one can only assure the absence of PAT in apple aromas if they are not mixed with apple juice to form a base for industrial applications.

\subsection{Storage of juice}

Around the world, the storage of concentrated juices under refrigeration or frozen storage is a common alternative to maintain their quality between harvests and/or for commercialization. If a juice at $70{ }^{\circ} \mathrm{Brix}$ is maintained under refrigeration $\left(5^{\circ} \mathrm{C}\right.$ or less), it will suffer no quality changes for at least 6 months. Juice at $40{ }^{\circ} \mathrm{Brix}$ is, however, normally maintained at temperatures equal or below $-20^{\circ} \mathrm{C}$, to avoid enzyme reactions and the growth of deteriorative yeasts.

Koca \& Eksi (2005) carried out the only published study on the effect of storage time and temperature on the levels of PAT in concentrated juice. The authors evaluated the effect of the storage temperature $\left(22^{\circ} \mathrm{C}\right.$ and $\left.30^{\circ} \mathrm{C}\right)$ on concentrated apple juices (70$74^{\circ}$ Brix) for a period of 6 months, using naturally contaminated apple juices containing 64, 105 and 150 ppb mycotoxin. The results showed that the reduction of PAT depended on the storage time and temperature, with greater reductions in the mycotoxin levels occurring at $30{ }^{\circ} \mathrm{C}(66-86 \%)$ than at $22{ }^{\circ} \mathrm{C}(45-64 \%)$ after one month of storage. After 4 months of storage at these temperatures, the levels of PAT were below the detection limit of the method (10 ppb). Although up to the present moment no study has been published evaluating the behaviour of juices containing PAT during frozen storage, based on the above-described results, it is to be expected that the levels of mycotoxin would not reduce during low temperature storage.

\subsection{Formulation}

PAT levels in formulated juices/nectars may be affected by added ingredients. Brackett \& Marth (1979b) were the first to demonstrate the instability of PAT to ascorbic acid and ascorbate, showing the rapid disappearance of the mycotoxin at $25^{\circ} \mathrm{C}$ after adding $2 \%$ of this compound to phosphate buffer containing the toxin. At this same temperature, they observed that in a buffer solution at $\mathrm{pH} 3.5$, the decrease in the levels of PAT increased with increase in vitamin C concentration ( $0,0.15 \%, 0.5 \%, 1.0 \%$ and $3.0 \%$ ). In apple juice containing $5 \%$ vitamin $C$, the loss of PAT was greater than in the juice without the addition of this vitamin, but the loss was slower than in the buffer solution, showing that the product components influence the PAT reduction rate. In addition to ascorbic acid, the addition of $\mathrm{B}$ complex vitamins: thiamine hydrochloride, pyridoxine hydrochloride and calcium pantothenate, can cause significant reductions in the levels of PAT in apple juice (Yazici \& Velioglu, 2002), although their addition would increase production costs. On evaluating the stability of PAT in a model system (buffer solution) with added ascorbic acid, Drusch, Kopka, \& Kaeding (2007) observed a reduction in the level of the mycotoxin to $30 \%$ of its initial concentration after 34 days in the presence of ascorbic acid, as compared to a reduction to $68-71 \%$ in the samples without ascorbic acid. Thus, the authors concluded that the storage conditions (presence of light, oxygen and/or metal ions) influenced PAT stability. In addition, since the decomposition of PAT occurs by way of free radicals generated by the oxidation of ascorbic or dehydroascorbic acids, when all the ascorbic acid has been oxidised, degradation of PAT is no longer observed. The authors therefore concluded that due to the low oxygen levels present in the headspace of juice packages, the addition of ascorbic acid before filling cannot be considered as an effective decontamination strategy.

Another additive that can be used in apple juice is sulphur dioxide. PAT was shown to be unstable in the presence of sulphur dioxide in an aqueous solution (Pohland \& Allen, 1970). Burroughs (1977) obtained $12 \%$ and $90 \%$ reductions in the levels of PAT in juices after 24 and $48 \mathrm{~h}$, respectively, using $200 \mathrm{ppm}$ of sulphur dioxide. A concentration of $100 \mathrm{ppm}$ of sulphur dioxide caused an immediate reduction of $50 \%$ in the levels of PAT (Ough \& Corison, 1980), and Aytac \& Acar (1994) obtained a reduction of $42 \%$ in the level of PAT using $100 \mathrm{mg}$ sulphur dioxide per $\mathrm{kg}$ juice.

Some additives, as ascorbic acid, are able to destroy PAT molecules, however it is known that in some cases, PAT is bound to proteins. This can lead to an underestimation of up to $20 \%$ of PAT level when apple juice is analysed for this mycotoxin (Baert et al., 2007). If the by-products present toxic activity, even in a minor nature when compared to PAT molecule is not clear at this moment. The use of a proper biological test system would be helpful to evaluate the toxic effects of PAT by-products after total or partial inactivation by food additives or by the apple juice processing steps.

In addition to being considered food grade additives, having some specific effect to improve or maintain some quality characteristic of the juices, food chemicals can be effective in controlling the growth of PAT producing moulds in the final product, such that they have a double function in the control of PAT (Moake, PadillaZakour, \& Worobo, 2005). Despite studies indicating the addition of some preservatives such as sulphur dioxide, sodium benzoate and potassium sorbate to inhibit the growth and production of PAT by B. nivea (Roland \& Beuchat, 1984; Roland, Beuchat, Worthington, \& Hitchcock, 1984), and potassium sorbate to inhibit the growth and production of PAT by P. expansum and Penicillium patulum (Bullerman \& Olivigni, 1974; Lennox \& McElroy, 1984), the consumer demand for healthy foods free of additives may represent an impediment to the use of such techniques. Apart from questions of cost, since the aseptic process currently applied assures the stability of the products during their shelf life, the use of such compounds it seems to be discouraged nowadays. Thus, it is preferable to use treatments that guarantee the elimination/inactivation of the ascospores of the heat resistant fungi (as filtration with diatomaceous earth as verified by King et al., 1969) than to apply these additives.

\subsection{Second pasteurization}

The amount of PAT present in the final product will depend on the initial concentration of the toxin in the concentrate, on the solids content and final pH, on the additives added (ascorbic and citric acids) and of the combined effect of these with the pasteurization temperature of the apple nectar. The reduction in PAT should be less pronounced in the case of the manufacture of apple juice. Although the lack of studies on the effect of different formulations (nectar and juice), pasteurized under conditions equivalent to those used by the industries, on the levels of the mycotoxin, does not allow for concrete conclusions to be made.

\subsection{Filling}

It is possible that the level of the mycotoxin is, to some extent, affected by the type of packaging material used. There is a possibility that the different chemical compositions and properties of the materials used result in different atmospheres within the materi- 
als, affecting the growth and production of PAT by the heat resistant fungi.

\subsection{Storage and commercialization}

Despite the fact that some studies indicate the stability of PAT during this stage or of slight reductions in their levels (Pohland \& Allen, 1970; Scott \& Somers, 1968), as described in Section 3.9, it is important to consider the possibility of heat resistant fungi surviving pasteurization and encountering conditions to multiply and produce PAT during storage, reaching values above those internationally permitted $(50 \mu \mathrm{g} / \mathrm{L})$, which is particularly relevant when one considers that the pasteurized juices filled aseptically, will be maintained at room temperature throughout commercialization. This question and the influence of the packaging material on the production of PAT are currently under research in our laboratory.

\section{Conclusions}

Despite the various stages of the manufacturing process of apple juice being capable of reducing the amount of PAT in the final products to a certain extent, the incidence of this mycotoxin in products throughout the World, confirms its stability to some degree when faced with the techniques currently in use.

Pre-harvest, harvest and post-harvest stages dictate the quality of the fruits that will be commercialized or used for juice processing. Thus, the adoption of adequate controls in the field, taking care not to damage the fruit during the harvest, and the rejection of those that fall to the ground, will lead to a reduction in the incidence of damage and rot during fruit storage, with a consequent reduction in the levels of PAT in the formulated products. On considering the industrial stages, the establishment of criteria for the acceptance and quality of the fruits on reception can have a great impact on the quality of the manufactured products, impeding the entrance of unsatisfactory fruit batches into the production line. In this sense, the awareness and training of the employees and the application of good agricultural practices have a preponderant role, since the selection is a procedure capable of eliminating the majority of the fruits contaminated with high levels of PAT. A reduction in the amount of damaged fruits or of those showing some rotten parts, will make the washing, selection and trimming stages more efficient, consequently reducing the levels of toxin in the final product. These can be considered as the most efficient stages within the factory with respect to the reduction in the levels of PAT.

Despite various studies proposing new clarification and filtering techniques, the majority come up against problems related to alterations in juice quality, costs, impact on the environment and somewhat difficult practical applicability. The commercially employed concentration and pasteurization stages are incapable of eliminating and/or significantly reducing the levels of PAT, due to its great heat stability in acidic environments, showing that it is always preferable to control and reduce the production of the mycotoxin in the fruits, than try to remove or inactivate it during processing of the juice. As described above, the addition of ascorbic acid can lead to a certain reduction in the levels of PAT in apple juice, however, in some countries around the world, the addition of this additive is not permitted when the fruit juice is produced, limiting its use for PAT reduction.

Confirmation of the ability of heat resistant fungi such as $\mathrm{B}$. $n i$ vea to produce PAT in packaged pasteurized juices, could suggest that the measures adopted to improve the quality and safety of apple juice should not restrict themselves to the control of the mycotoxin per se and to the microorganisms related to the fruit handling stages, but also to the control of microorganisms capable of pro- ducing PAT post-pasteurization. In this way, the filtration of apple juice with diatomaceous earth should be considered as a critical control point to assure the elimination of ascospores of heat resistance fungi and a possible PAT production.

In addition to being an object of concern from the food safety point of view, the presence of PAT is also an indication of the use of low quality raw materials in the manufacture of the juice, and only by a greater interaction between the industrial sector and the fruit producers will we manage to make high quality, safe products available to the consumer.

\section{Acknowledgements}

The authors thank to Conselho Nacional de Desenvolvimento Científico e Tecnológico (CNPQ) for fellowship to Anderson de Souza Sant'Ana, to Fundo de Apoio Ao Ensino, à Pesquisa e à Extensão (FAEPEX) (Processes 282/06 and 129/07) and to Prodetab (Embrapa) for providing funds for this research.

\section{References}

Acar, J., Gökmen, V., \& Taydas, E. E. (1998). The effects of processing technology on the patulin content of juice during commercial apple juice concentrate production. Zeitschrift fur Lebensmittel-Untersuchung und -Forschung A (European Food Research and Technology), 207, 328-331.

Arafat, W., \& Musa, M. N. (1995). Patulin-induced inhibition of protein synthesis in hepatoma tissue culture. Research Communications in Molecular Pathology $\mathcal{F}^{\circ}$ Pharmacology, 87, 177-186.

Aytac, S. A., \& Acar, J. (1994). Einflub von L-ascorbinsäure und schwefeldioxidzusatz auf die stabilität von patulin in apfeläften und pufferlösungen. Ernährung, 1, 15-17.

Baert, K., Meulenaer, B., Kamala, A., Kasase, C., \& Devlieghere, F. (2006). Occurrence of patulin in organic, conventional, and handcrafted apple juices marketed in Belgium. Journal of Food Protection, 69, 1371-1378.

Baert, K., Meulenaer, B., Kamala, A., Kasase, C., Huyghebaert, A., Ooghe, W., et al. (2007). Free and bound patulin in cloudy apple juice. Food Chemistry, 100, 1278-1282.

Beretta, B., Gaiaschi, A., Galli, C. L., \& Restani, P. (2000). Patulin in apple-based foods: Occurrence and safety evaluation. Food Additives and Contaminants, 17, 399-406.

Bissessur, J., Permaul, K., \& Odhav, B. (2001). Reduction of patulin during apple juice clarification. Journal of Food Protection, 64, 1216-1219.

Boneti, J. I. S., \& Katsurayama, Y. (1998). Doenças da macieira. Estação Experimental de São Joaquim (Epagri) (pp. 1-85). São Paulo: Basf.

Boonzaaijer, G., Bobeldijk, I., \& van Osenbruggen, W. A. (2005). Analysis of patulin in Dutch food, an evaluation of a SPE based method. Food Control, 16, 587-591.

Brackett, R. E., \& Marth, E. H. (1979a). Patulin in apple juice from roadside stands in Wisconsin. Journal of Food Protection, 42, 862-863.

Brackett, R. E., \& Marth, E. H. (1979b). Ascorbic acid and ascorbate cause disappearance of patulin from buffer solutions and apple juice. Journal of Food Protection, 42, 864-866.

Brasil (1988). Resolução ${ }^{\circ} 4$, de 24 de novembro de 1988 . Aprova a revisão das Tabelas I, III, IV e V referente a Aditivos Intencionais. Diário Oficial da União, 19 de novembro de 1988 .

Bullerman, L. B., \& Olivigni, F. J. (1974). Mycotoxin producing potential of molds isolated from cheddar cheese. Journal of Food Science, 39, 1166-1168.

Burda, K. (1992). Incidence of patulin in apple, pear, and mixed fruit products marketed in New South Wales. Journal of Food Protection, 55, 796-798.

Burroughs, L. F. (1977). Stability of patulin to sulfur dioxide and to yeast fermentation. Journal of AOAC International, 60, 100-103.

Calvo, J., Calvente, V., Orellano, M. E., Benuzzi, D., \& Tosetti, M. I. S. (2007). Biological control of postharvest spoilage caused by Penicillium expansum and Botrytis cinerea in apple by using the bacterium Rahnella aquatilis. International Journal of Food Microbiology, 113, 251-257.

Canãs, P., \& Aranda, M. (1996). Decontamination and inhibition of patulin-induced cytotoxicity. Environmental Toxicological and Water Quality, 11, 249-253.

CDC (1996). Outbreak of Escherichia coli 0157:H7 infections associated with drinking unpasteurized commercial apple juice - British Columbia, California, Colorado and Washington. Morbidity and Mortality Weekly Report, 45(October), 975.

CDC (1997). Outbreaks of Escherichia coli 0157:H7 infections and cryptosporidiosis associated with drinking unpasteurized apple cider - Connecticut and New York, 1996. Morbidity and Mortality Weekly Report, 46(October), 4-8.

Cerny, Y. G., Hennlich, W., \& Poralla, K. (1984). Spoilage of fruit juice by bacilli: Isolation and characterization of the spoiling microorganism. Zeitschrift fur Lebensmittel-Untersuchung und -Forschung (European Food Research and Technology), 179, 224-227.

Chen, L., Ingham, B. H., \& Ingham, S. C. (2004). Survival of Penicillium expansum and patulin production on stored apples after wash treatments. Journal of Food Science, 69, 669-675. 
Cheraghali, A. M., Mohammadi, H. R., Amirahmadi, M., Yazdanpanah, H., Abouhossain, G., Zamanian, F., et al. (2005). Incidence of patulin contamination in apple juice produced in Iran. Food Control, 16, 165-167.

CODEX - Codex Committee on Food Additives and Contaminants (2003a). Maximum level for patulin in apple juice and apple juice ingredients and other beverages. Codex Stan, 235, 1.

CODEX - Codex Alimentarius Commission (2003b). Code of practice for the prevention and reduction of patulin contamination in apple juice and apple juice ingredients in other beverages. $C A C / R C P, 50,1-6$.

CODEX - Codex Alimentarius Commission (2005). Codex general standard for fruit juices and nectars. Codex Stan, 247, 1-15.

Conway, W. S., Janisiewicz, W. J., Klein, J. D., \& Sams, C. E. (1999). Strategy for combining heat treatment, calcium infiltration, and biological control to reduce postharvest decay of "Gala" apples. HortScience, 34, 700-704.

Cooray, R., Kiessling, K. H., \& Lindahl-Kiessling, K. (1982). The effects of patulin and patulin-cysteine mixtures on DNA synthesis and the frequency of sisterchromatid exchanges in human lymphocytes. Food and Chemical Toxicology, 20, 893-898.

Draughon, F. A., \& Ayres, J. C. (1980). Insecticide inhibition of growth and patulin production in Penicillium expansum, Penicillium urticae, Aspergillus clavatus, Aspergillus terreus, and Byssochlamys nivea. Journal of Agricultural and Food Chemistry, 28, 1115-1117.

Drusch, S., Kopka, S., \& Kaeding, J. (2007). Stability of patulin in a juice-like aqueous model system in the presence of ascorbic acid. Food Chemistry, 100, 192-197.

Errampali, D. (2004). Effect of fluidioxinil on germination and growth of Penicillium expansum and decay in apple cvs. Empire and Gala. Crop Protection, 23, 811-817.

Errampali, D., Northover, J., Skog, L., Brubacher, N. R., \& Colluci, C. A. (2005). Control of the blue mold(Penicillium expansum) by fludioxinil in apples (cv Empire) under controlled atmosphere and cold storage conditions. Pest Management Science, 61, 591-596.

Escoula, L., Moore, J., \& Baradat, C. (1977). The toxins of Byssochlamys nivea Part I. Acute toxicity of patulin in adult rats and mice. Annals de Recherche Vétérinaire, $8,41-49$.

EUROPEAN UNION (2003). Commission Regulation no. 1425/2003 amending Commission Regulation no. 466/2001 setting maximum levels for certain contaminants in foodstuffs, Brussels, Belgium. Official Journal of the European Communities, L203, 1-3.

FAO - Food and Agriculture Organization of the United Nations (2003). Manual on the application of the HACCP system in mycotoxin prevention and control. FAO Food and Nutrition Paper, 73, 1-124.

Faragher, J. (2000). Storage conditions affecting the life of fruit. Agriculture Notes(June), 1-3.

FDA - United States Food and Drug Administration (2000). Patulin in apple juice, apple juice concentrates and apple juice products. <www.cfsan.fda.gov/ dms/ patubckg.html>.

Gentry, T. S., \& Roberts, J. S. (2004). Formation kinetics and application of 5hydroxymethylfurfural as a time-temperature indicator of lethality for continuous pasteurization of apple cider. Innovative Food Science and Emerging Technologies, 5, 327-333.

Girardi, C., \& Bender, R. J. (2003). Produção Integrada de Maçãs no Brasil. Colheita e Pós-colheita. Embrapa Uva e Vinho. <http://sistemasdeproducao.cnptia.embrapa. br/FontesHTML/Maca/ProducaoIntegradaMaca/colheita.htm>.

Gökmen, V., \& Acar, J. (1998). Incidence of patulin in apple juice concentrates produced in Turkey. Journal of Chromatography A, 815, 99-102.

Gökmen, V., \& Acar, J. (2000). Long-term survey of patulin in apple juice concentrates produced in Turkey. Food Additives and Contaminants, 17, 933-936.

Gökmen, V., Artik, N., Acar, J., Kaharaman, N., \& Poyrazoglu, E. (2001). Effects of various clarification treatments on patulin, phenolic compound and organic acid compositions of apple juice. European Food Research Technology, 213, 194-199.

Harrison, M. A. (1989). Presence and stability of patulin in apple products: A review. Journal of Food Safety, 9, 147-153.

Hasan, H. A. H. (2000). Patulin and aflatoxin in brown rot lesion of apple fruits and their regulation. World Journal of Microbiology \& Biotechnology, 16, 607-612.

Hayes, A. W., Phillips, T. D., Williams, W. L., \& Ciegler, A. (1979). Acute toxicity of patulin in mice and rats. Toxicology, 13, 91-100.

Heatley, N. E., \& Philpot, F. J. (1947). The routine examination for antibiotics produced by moulds. Journal of General Microbiology, 1, 232-237.

Hopkins, J. (1993). The toxicological hazards of patulin. Food and Chemical Toxicology, 31, 455-456.

Huebner, H. J., Mayura, K., Pallaroni, L., Ake, C. L., Lemke, S. L., Herrera, P., et al. (2000). Development and characterization of a carbon-based composite material for reducing patulin levels in apple juice. Journal of Food Protection, $63,106-110$.

Iha, M. H., \& Sabino, M. (2008). Incidence of patulin in Brazilian apple-based drinks. Food Control, 19, 417-422.

Jackson, L. S., Beacham-Bowden, T., Keller, S. E., Adhikari, C., Taylor, K. T., Chirtel, S. J., et al. (2003). Apple quality, storage, and washing treatments affect patulin levels in apple cider. Journal of Food Protection, 66, 618-624.

Kadakal, C., \& Nas, S. (2002a). Effect of activated charcoal on patulin, fumaric acid, and some other properties of apple juice. Nahrung/Food, 46, 31-33.

Kadakal, C., \& Nas, S. (2002b). Effect of apple decay proportion on the patulin, fumaric acid, HMF and other apple juice properties. Journal of Food Safety, 22, 17-25.

Kadakal, C., \& Nas, S. (2003). Effect of heat treatment and evaporation on patulin and some other properties of apple juice. Journal of the Science of Food and Agriculture, 83, 987-990.
Kadakal, C., Sebahattin, N., \& Poyrazoglu, E. S. (2002). Effect of commercial processing stages of apple juice on patulin, fumaric acid and hydroxymetilfurfural (HMF) levels. Journal of Food Quality, 25, 359-368.

Karow, E. O., \& Foster, J. W. (1944). An antibiotic substance from species of Gymnoascus and Penicillium. Science, 99, 265-266.

King, A. D., Michener, H. D., \& Ito, K. A. (1969). Control of Byssochlamys and related heat-resistant fungi in grape products. Applied Microbiology, 18, 166-173.

Koca, N., \& Eksi, A. (2005). Reduction of patulin in apple juice concentrates during storage. Journal of Food Safety, 25, 1-8.

Kryger, R. A. (2001). Volatility of patulin in apple juice. Journal of Agricultural and Food Chemistry, 49, 4141-4143.

Kubacki, S. J. (1986). The analysis and occurrence of patulin in apple juice. In P. S Steyn \& R. Vieggaar (Eds.), Mycotoxins and phycotoxins (pp. 293-304). Amsterdam: Elsevier

Kupferman, E. (2001). Controlled atmosphere storage of apples and pears. Postharvest Information Network(December), 1-8.

Laidou, I. A., Thanassoulopoulos, C. C., \& Liakopoulou-Kyriakides, M. (2001) Diffusion of patulin in the flesh of pears inoculated with four post-harvest pathogens. Journal of Phytopathology, 149, 457-461.

Lea, A. G. H. (1990). Apple juice. In D. Hicks (Ed.), Production and packaging of noncarbonated fruit juices and fruit beverages (pp. 182-225). Glasgow: Blackie and Son.

Leblanc, J. C., Tard, A., Volatier, J. L., \& Verger, P. (2005). Estimated dietary exposure to principal food mycotoxins from The First French Total Dietary study. Food Additives and Contaminants, 22, 652-672.

Leggott, N. L., \& Shephard, G. S. (2001). Patulin in South African commercial apple products. Food Control, 12, 73-76.

Leggott, N. L., Sheppard, G. S., Stockenström, S., Staal, E., \& van Schalkwyk, D. J. (2001). The reduction of patulin in apple juice by three different types of activated carbon. Food Additives and Contaminants, 18, 825-829.

Leggott, N. L., Vismer, H. F., Sydenham, E. W., Shephard, G. S., Rheeder, J. P., \& Marasas, W. F. O. (2000). Occurrence of patulin in the commercial processing of apple juice. South African Journal of Science, 96, 241-243.

Lennox, J. E., \& McElroy, L. J. (1984). Inhibition of growth and patulin synthesis in Penicillium expansum by potassium sorbate and sodium propionate in culture. Applied and Environmental Microbiology, 48, 1031-1033.

Lindroth, S., \& Niskanen, A. (1978). Comparison of potential patulin hazard in homemade and commercial apple products. Journal of Food Science, 43.

Little, C. R., \& Holmes, R. J. (2000). Postharvest pathology of apples and pears. In J Faragher (Ed.), Storage technology for apples and pears (pp. 154-197). Victoria: Department of Natural Resources and Environment.

Lovett, J., \& Peeler, J. T. (1973). Effect of pH on the thermal destruction kinetics of patulin in aqueous solution. Journal of Food Science, 38, 1094-1095.

Lovett, J., Thompson, R. G., \& Boutin, B. K. (1975). Patulin production in apples stored in a controlled atmosphere. Journal of AOAC, 58, 912-914.

Mahfoud, R., Maresca, M., Garmy, N., \& Fantini, J. (2002). The mycotoxin patulin alters the barrier function of the intestinal epithelium: Mechanism of action of the toxin and protective effects of glutathione. Toxicology and Applied Pharmacology, 181, 209-218.

Manchisky, M., \& Mídio, A. F. (1996). Incidencia de patulina en jugo de manzana industrializado. Alimentaria, 276, 61-64.

Marin, S., Morales, H., Hasan, H. A., Ramos, A. J., \& Sanchis, V. (2006). Patulin distribution in Fuji and Golden apples contaminated with Penicillium expansum. Food Additives and Contaminants, 23, 1316-1322.

Martins, M. L., Gimeno, A., Martins, H. M., \& Bernardo, F. (2002). Co-occurrence of patulin and citrinin in Portuguese apples with rotten spots. Food Additives and Contaminants, 19, 568-574

Miller, C. J., \& Lyndon, R. M. (2001). Process for reducing the patulin concentration in fruit juices. United States Patent No. 6,248,382 B1, June 19, pp. 1-13.

Moake, M. M., Padilla-Zakour, O. I., \& Worobo, R. W. (2005). Comprehensive review of patulin control methods in foods. Comprehensive Reviews in Food Science and Food Safety, 1, 8-21.

Moodley, R. S., Goviden, R., \& Odhav, B. (2002). The effect of modified atmospheres and packaging on patulin production in apples. Journal of Food Protection, 65 867-871.

Morales, H., Marin, S., Rovira, A., Ramos, A. J., \& Sanchis, V. (2007a). Patulin accumulation in apples by Penicillium expansum during postharvest stages. Letters in Applied Microbiology, 44, 30-35.

Morales, H. Marín, S., Centelles, X., Ramos, A. J. \& Sanchis, V. (2007b). Cold and ambient deck storage prior to processing as a critical control point for patulin accumulation. International Journal of Food Microbiology, 116, 260-265.

Morales, H., Sanchis, V., Rovira, A., Ramos, A. J., \& Marin, S. (2007). Patulin accumulation in apples during postharvest: Effect of controlled atmosphere storage and fungicide treatments. Food Control, 18, 1443-1448.

Moule, Y., \& Hatey, F. (1977). Mechanism of the in vitro inhibition of transcription by patulin, a mycotoxin from Byssochlamys nivea. FEBS Letters, 74, 121-125.

Mutlu, M., \& Gökmen, V. (1998). Determination of effective mass transfer coefficient $\left(K_{\mathrm{c}}\right)$ of patulin adsorption on activated carbon packed bed columns with recycling. Journal of Food Engineering, 35, 259-266.

Neri, F., Mari, M., Menniti, A. M., Brigati, S., \& Bertolini, P. (2006). Control of Penicillium expansum in pears and apples by trans-2-hexenal vapours. Postharvest Biology and Technology, 41, 101-108.

Okull, D. O., \& Laborde, L. F. (2004). Activity of electrolyzed oxidizing water agains Penicillium expansum in suspension and wounded apples. Journal of Food Science, 69, S23-S27.

Ough, C. S., \& Corison, C. A. (1980). Measurement of patulin in grapes and wines. Journal of Food Science, 45, 476-478. 
Paster, N., Huppert, D., \& Barkai-Golan, R. (1995). Production of patulin by different strains of Penicillium expansum in pear and apple cultivars stored at different temperatures and modified atmospheres. Food Additives and Contaminants, 12, 51-58.

Pfeiffer, E., Groß, K., \& Metzler, M. (1998). Aneuploidogenic and clastogenic potential of the mycotoxins citrinin and patulin. Carcinogenesis, 19, 1313-1318.

Piemontese, L., Solfrizzo, M., \& Visconti, A. (2005). Occurrence of patulin in conventional and organic fruit products in Italy and subsequent exposure assessment. Food Additives and Contaminants, 22, 437-442.

Pohland, A. E., \& Allen, R. (1970). Stability studies with patulin. Journal of AOAC International, 53, 688-691.

Prado, G., Oliveira, M. S., Cunha, M. R., Gomides, M. F. Abrantes, F. M., Santos, L. G., et al. (2000). Occurrence of patulin in apple juice marketed in Brasil by highperformance liquid chromatography. Revista do Instituto Adolfo Lutz, 59, 21-25.

Prieta, J., Moreno, M. A., Díaz, S., Suárez, G., \& Dominguez, L. (1994). La patulina como indicador de calidad em productos elaborados com manzana. Alimentaria, $254,75-80$

Ritieni, A. (2003). Patulin in Italian commercial apple products. Journal of Agricultural and Food Chemistry, 51, 6086-6090.

Roland, J. O., \& Beuchat, L. R. (1984). Biomass and patulin production by Byssochlamys nivea in apple juice as affected by sorbate, benzoate, $\mathrm{SO}_{2}$ and temperature. Journal of Food Science, 49, 402-406.

Roland, J. O., Beuchat, L. R. Worthington, R. E., \& Hitchcock, H. L. (1984). Effects of sorbate, benzoate, sulfur dioxide and temperature on growth and patulin production by Byssochlamys nivea in grape juice. Journal of Food Protection, 47, 237-241.

Roll, R., Matthiaschk, G., \& Korte, A. (1990). Embryotoxicity and mutagenicity of mycotoxins. Journal of Environmental Pathology, Toxicology and Oncology, 10, 1-7.

Root, W. H., \& Barret, D. M. (2005). Apples and apple processing. In D. M. Barret, Somogyi, \& H. Ramaswamy (Eds.), Processing fruits: Science and technology (pp. 455-480). Boca Raton: CRC Press.

Rutledge, P. (1996). Production of non-fermented fruit products. In D. Arthey \& P. R. Ashurst (Eds.), Fruit processing (pp. 70-94). Cambridge: Chapman \& Hall.

Rychlik, M., \& Schieberle, P. (2001). Model studies on the diffusion behavior of the mycotoxin patulin in apples, tomatoes, and wheat bread. European Food Research Technology, 212, 274-278.

Sanderson, P. G., \& Spotts, R. A. (1995). Postharvest decay of winter pear and apple fruit caused by species of Penicillium. Phytopathology, 85, 103-110.

Sands, D. C., McIntyre, J. L., \& Walton, G. S. (1976). Use of activated charcoal for the removal of patulin from cider. Applied and Environmental Microbiology, 32 388-391.

Sanhueza, R. M. V. (1996). Recomendações para o controle pós-colheita das podridões de maçãs. Embrapa. Comunicado Técnico, 21, 1-4.

Scott, P. M., \& Somers, E. (1968). Stability of patulin and penicillic acid in fruit juices and flour. Journal of Agricultural and Food Chemistry, 16, 483-485.

Spadaro, D., Ciavorella, A., Frati, S., Garibaldi, A., \& Gullino, M. L. (2007). Incidence and level of patulin contamination in pure and mixed apple juices marketed in Italy. Food Control, 18, 1098-1102.
Spotts, R., \& Cervantes, L. A. (1986). Population, pathogenicity and benomyl resistance of Botrytis spp., Penicillium spp. and Mucor piriformis in packinghouses. Plant Diseases, 70, 106-108.

Stott, W. T., \& Bullerman, L. B. (1975). Patulin: A mycotoxin of potential concern in foods. Journal of Food Protection, 38, 695-705.

Swindeman, A. M. (2002). Fruit packing and storage loss prevention guidelines. Postharvest Information Network(December), 1-9.

Sydenham, E. W., Vismer, H. F., Marasas, W. F. O., Brown, N., Schlechter, M., van der Westhuizen, L., et al. (1995). Reduction of patulin in apple juice samples influence of initial processing. Food Control, 6, 195-200.

Sydenham, E. W., Vismer, H. F., Marasas, W. F. O., Brown, N. L., Schlechter, M., \& Rheeder, J. P. (1997). The influence of deck storage and initial processing on patulin levels in apple juice. Food Additives and Contaminants, 14, 429-434.

Sylos, C. M., \& Rodriguez-Amaya, D. B. (1999). Incidence of patulin in fruits and fruits juices marketed in Campinas, Brazil. Food Additives and Contaminants, 16 , 71-74.

Tangni, E. K., Theys, R., Mignolet, E., Maudoux, M., Michelet, J. Y., \& Larondelle, Y. (2003). Patulin in domestic and imported apple-based drinks in Belgium: Occurrence and exposure assessment. Food Additives and Contaminants, 20, 482-489.

Taniwaki, M. H., Bleinroth, E. W., \& De Martin, Z. J. (1989). Bolores produtores de patulina em maçã e suco industrializado. Coletânea do Instituto de Tecnologia de Alimentos, 19, 42-49.

Taniwaki, M. H., Hoenderboom, C. J. M., Vitali, A. A., \& Eiroa, M. N. U. (1992). Migration of patulin in apples. Journal of Food Protection, 55, 902-904.

Watanabe, M., \& Shimizu, H. (2005). Detection of patulin in apple juices marketed in the Tohoku District, Japan. Journal of Food Protection, 68, 610-612.

Watkins C. B., Kupferman, E., \& Rosenberger, D. A. (2002). Apple. Postharvest quality maintenance guidelines. In K. C. Gross, C. Y. Wang, \& M. Saltveit (Eds.), The commercial storage of fruits, vegetables, and florist and nursery crops. <http:// usna.usda.gov/hb66/027apple.pdf>

Watkins, K. L., Fazekas, G., \& Palmer, M. V. (1990). Patulin in Australian apple juice. Food Australia, 42, 438-439.

Wheeler, J. L., Harrison, M. A., \& Koehler, P. E. (1987). Presence and stability of patulin in pasteurized apple cider. Journal of Food Science, 52, 479-480.

Wichmann, G., Herbarth, O., \& Lehmann, I. (2002). The mycotoxins citrinin, gliotoxin, and patulin affect interferon-g rather than interleukin-4 production in human blood cells. Environmental Toxicology, 17, 211-218.

Wiesner, B. P. (1942). Bactericidal effects of Aspergillus clavatus. Nature, 149, 356-357.

Wosiacki, G., \& Nogueira, A. (2005). Suco de Maçã. In W. G. Venturini Filho (Ed.), Tecnologia de bebidas (pp. 255-292). São Paulo: Edgard Blücher.

Yazici, S., \& Velioglu, S. (2002). Effect of thiamine hydrochloride, pyridoxine hydrochloride and calcium- $d$-pantothenate on the patulin content of apple juice concentrate. Nahrung/Food, 46, 256-257.

Yurdun, T., Omurtag, G. Z., \& Ersoy, O. (2001). Incidence of patulin in apples juices marketed in Turkey. Journal of Food Protection, 64, 1851-1853. 